\title{
Architektura systemu finansowego jednostek samorządu terytorialnego
}

\author{
Krystyna Piotrowska-Marczak \\ Prof. zw. dr hab., \\ Wyższa Szkoła Bankowa w Toruniu \\ http://dx.doi.org/10.18778/8088-114-3.02
}

\section{Wprowadzenie}

Specyfika każdego systemu wymaga uwzględnienia szerszego kontekstu, w którym on występuje. Punktem odniesienia jest pojęcie systemu i jego metodologiczne uwarunkowania. Na tym tle umieszczone zostały rozważania poświęcone systemowi finansów publicznych i jego części, jaką jest system finansowy jednostek samorządu terytorialnego. Na nim skoncentrowany jest dalszy wywód, oparty na analizie formalnej i funkcjonalnej obejmującej dochody i wydatki za lata 2010-2014. Na tej podstawie przedstawiona jest ocena systemu z punktu widzenia jego spójności, realizacje założonych celów społecznych i ekonomicznych. Stwarza to bazę do sformułowania konkluzji zmierzającej do stwierdzenia, czy architektura systemu finansowego jednostek samorządu terytorialnego pozwala na racjonalną gospodarkę finansową środkami publicznymi.

\section{Pojęcie systemu i jego metodologiczne uwarunkowania}

Zgodnie z prakseologicznym podejściem system to zbiór elementów mających określoną strukturę, tworzącą całość o innych cechach niż cechy elementów ${ }^{1}$. Nie jest to zatem przypadkowy układ, ale taki, w którym poszczególne części są ze sobą powiązane określonymi relacjami. To powoduje, że system to całość jakościowo różna od prostej

1 Por. T. Pszczołowski, Mała encyklopedia prakseologii i teorii organizacji, Wrocław-Warszawa-Kraków 1978, s. 237. 
sumy elementów, a powiązane elementy systemu pozostają wzajemnie od siebie uzależnione.

Logiczna ocena systemu zawierać musi aksjomaty i reguły zgodnie, z którymi przebiega ich uzasadnienie ${ }^{2}$.

Dążenie do tworzenia systemu wynika z potrzeby regulacji procesów związanych z działaniem ludzi, w taki sposób, aby ograniczyć ich przypadkowy przebieg nie mający racjonalnych podstaw. Stąd każdy system powinna charakteryzować zdolność do realizacji określonego celu lub celów, wewnętrzna zgodność oraz względna stabilność ${ }^{3}$.

Z teleologicznego punktu widzenia systemów może być bardzo wiele. Każdy z nich charakteryzuje się odmiennymi cechami, które wyznaczają jego profil w ujęciu podmiotowym i przedmiotowym ${ }^{4}$.

Wśród systemów, które mają związek z systemem finansów publicznych, są systemy: prawa, społeczny i zarządzania. Każdy z nich posiada konkretne cechy, które go wyróżniają od innych. Cechy systemu finansów publicznych to: własność publiczna, cel, jakim jest zaspokojenie potrzeb społecznych ze środków publicznych, realizowanych przez sieć instytucji, których zasady działania i organizacji wyznaczają normy prawne ustalające konstrukcję instrumentów finansowych, przy pomocy których dokonuje się redystrybucja zgromadzonych środków publicznych ${ }^{5}$.

W systemie finansów publicznych można wyodrębnić podsystemy, które związane są z podziałem środków publicznych pozostających w dyspozycji państwa i samorządów terytorialnych. Zgodnie $\mathrm{z}$ teorią funkcjonalną elementy podsystemów mogą, choć nie muszą, wypełniać funkcje mające wpływ na cały system ${ }^{6}$. T. Parsons sugeruje, że każdy system spełnia następujące funkcje: opóźnienia lub utrzymania motywacji nadających kierunek działaniu ograniczającemu wahania systemu, realizacji celów i osiągnięcia określonych rezultatów oraz adaptacji związanej z powiązaniem systemu $\mathrm{z}$ otoczeniem. Zadaniem prawa jest taka jego konstrukcja, aby system był jednolity i spójny. Podstawę do tego daje z jednej strony określona struktura prawa, a z drugiej elementy, które się na to składają ${ }^{7}$. Zgodnie z podejściem funkcjonalnym prawo stanowi „(...) wyraz społecznej funkcji nadzorowania wypełnianej przez instytucje społeczne"».

Takie podejście wydaje się szczególnie ważne i ściśle związane z finansami publicznymi i prawem finansowym, gdyż szczególną rolę w tym

2 Encyklopedia logiki, Wrocław-Warszawa-Kraków 1970, s. 237.

3 Por. S. Owsiak, Finanse publiczne. Teoria i praktyka, Warszawa 2005, s. 375.

4 Por. Encyklopedia Organizacji i Zarządzania, Warszawa 1981 s. 508-518

5 Por. S. Owsiak, op. cit., s. 376.

6 Por. B. Dupret, Prawo w naukach społecznych, Warszawa 2010 s. 164.

7 Por. ibidem, s. 165.

8 Ibidem, s. 173. 
układzie odgrywa para nadawca-państwo i odbiorca-obywatel ${ }^{9}$. Charakter prawa, które te zależności reguluje, zależy od tego czy tworzy ono system spójny i skuteczny ze społecznego punktu widzenia. J. Habermas twierdzi, że „Jedyne prawo, które można uznać za prawomocne, to prawo, które może być racjonalnie zaakceptowane przez wszystkich obywateli $\mathrm{w}$ dyskursywnym procesie kształtowania opinii i woli" ${ }^{10}$. Tak rozumiane prawo winno być modyfikowane zgodnie z procesem ewolucji jakim podlega społeczeństwo. Wynika to z faktu, że prawo wypełnia wiele funkcji społecznych. Nie można jednak nie wskazać, że prawo jest narzędziem, którym posługuje się władza stosując przymus. Wyraźnie to się objawia w przypadku systemu finansowego i odnosi się do przymusu związanego $\mathrm{z}$ obowiązkiem podatkowym. Pieniądz jest, w tym przypadku, w rękach państwa aktywnym instrumentem oddziaływania na procesy ekonomiczne i społeczne ${ }^{11}$. Ze względu na zróżnicowany charakter tych procesów, jak już wskazano, system finansowy jest zdywersyfikowany i w ramach systemu finansów publicznych występuje podsystem finansów jednostek samorządu terytorialnego. Jego specyfika polega na tym, że powinien być skoncentrowany na dążeniu do rozwoju na szczeblu lokalnym. Wymaga to działań w sferze: społecznej, ekonomicznej i ekologiczno-przestrzennej $^{12}$. Zabezpieczenie dla aktywności jednostek samorządu terytorialnego wymienionych obszarach ma zapewnić odpowiednio skonstruowany system finansowy.

Zasadniczy problem $\mathrm{w}$ tym przypadku nie sprowadza się tylko do zapewnienia określonych rozmiarów środków, ale do wyboru modelu rozwoju separowanego, czy powiązanego ściśle z rozwojem całego kraju. Każde z rozwiązań w tym zakresie musi mieć swoje miejsce w strukturze systemu finansowego. W pierwszym $\mathrm{z}$ wskazanych przypadków wystarczy równowaga wewnętrzna systemu, natomiast $\mathrm{w}$ drugim konieczne jest uwzględnienie elementów umożliwiających historyczne zróżnicowanie rozwoju i sposób na uzyskanie względnej równowagi w tym zakresie. Ważna rolę mają tu rozmiary elastyczności odniesionej zarówno do dochodów, jaki i wydatków jednostek samorządu terytorialnego. O poziomie tej elastyczności decydują wagi, które dla krajów europejskich ustala $\mathrm{OECD}^{13}$. Ważny dla tego układu jest fakt, że podstawowym rodzajem dochodów publicznych są podatki, ale w tym przypadku powstaje pytanie, jakie jest ich znaczenie dla budżetu państwa a jakie dla budżetów samorządów terytorialnych.

9 Ibidem, s. 216.

10 Za: B. Dupret, op. cit., s. 111.

11 Por. S. Bolland, Wstęp do nauki finansów, Warszawa 1979, s. 66, 73.

12 Por. M. Kogut-Jaworska, Instrumenty interwencjonizmu lokalnego w stymulowaniu rozwoju gospodarczego, Warszawa 2008, s. 11.

13 Por. A. Moździerz, Nierównowaga finansów publicznych, Warszawa 2009, s. 86. 


\section{Specyfika systemu finansów systemu jednostek samorządu terytorialnego}

Rozważania poświęcone systemowi finansów samorządu terytorialnego w Polsce wymagają przedstawienia jego elementów składowych od strony formalnoprawnej analizy danych obrazujących gospodarkę finansową zarówno po stronie dochodów jak i wydatków. Pozwoli to na stwierdzenie, jaka jest faktyczna - realna architektura tego systemu, i jakim zmianom w czasie ulega. Pozwoli to na ocenę systemu, która powinna doprowadzić do stwierdzenia czy ma on cechy układu spójnego.

Aktualnie wyznaczony regulacjami prawnymi system jednostek samorządu terytorialnego „(...) tworzy całość zróżnicowaną, złożoną z wielu elementów, zatem jednak względnie uporządkowaną. Choć w ramach systemu mogą występować pewne (z reguły niezamierzone) sprzeczności w rozwiązaniach szczegółowych w stosunku do ogólnych zasad i założeń, to jednak występują także podstawowe rozwiązania, które umożliwiają przyjęcie, że oceniany system jest zbiorem urządzeń spójnych dostatecznym stopniu uporządkowanych i spójnych" ${ }^{14}$. Przytoczony pogląd wyraźnie wskazuje, że system finansowy jednostek samorządu terytorialnego obowiązujący aktualnie w Polsce budzi wiele wątpliwości z punktu widzenia jego spójności, wewnętrznego porządku i logiki powiązań. W tym układzie symptomatyczna jest ocena dostateczna, co świadczy o jego niedoskonałości i daje asumpt do analizy braków wraz z propozycjami zmian, które winny być przedmiotem dyskusji.

Ocena istniejącego stanu narzuca potrzebę analizy elementów składowych systemu. W literaturze wymienia się ich następującą listę: „(...) instytucje prawne określające stosunki finansowe pomiędzy państwem i samorządem terytorialnym, instytucje budżetowe samorządu terytorialnego, system dochodów samorządowych, konstrukcje prawne dotyczące wydatków samorządu terytorialnego, rozwiązania w zakresie długu publicznego samorządu, organy i formy kontroli oraz nadzoru nad działalnością finansową jednostek samorządu terytorialnego"15. Trzy pierwsze z wymienionych elementów odgrywają najważniejszą rolę, bowiem świadczą, jakie są możliwości pozbawionego sprzeczności zarządzania gospodarka finansową jednostek samorządu terytorialnego. Jednostki samorządu terytorialnego wykonują zadania związane z zaspokajaniem potrzeb społeczności lokalnej, wymaga to zapewnienia udziału w środkach publicznych w takich rozmiarach, które odpowiadają realizacji tych zadań. W tym celu jednostki samorządu terytorialnego są wyposażone w osobowość prawną, posiada-

14 A. Borodo, Samorząd terytorialny. System prawnofinansowy, Warszawa 2004, s. 75.

15 Ibidem, s. 75. 
ją prawo własności i prawa majątkowe. Z finansowego punktu widzenia najważniejsza jest samodzielność finansowa jednostek samorządu terytorialnego. Teoretycznie powinna ona odnosić się zarówno do pozyskiwania dochodów jak ich przeznaczania na różne rodzaje wydatków. $Z$ tego tytułu samodzielność finansowa jednostek samorządu terytorialnego jest powiązana $\mathrm{z}$ władztwem dochodowym i wydatkowym. Aby taka sytuacja miała miejsce, muszą być spełnione określone warunki. W przypadku samodzielności dochodowej są to „(...) pewność i wydajność poszczególnych dochodów i wpływ władz samorządowych na ich kształtowanie"16. Aby zatem można było mówić o samodzielności dochodowej jednostek samorządu terytorialnego, muszą one posiadać dochody własne, własne mienie, dostęp do rynków finansowych oraz zapewnioną samodzielność w uchwalaniu budżetu ${ }^{17}$. Natomiast samodzielność wydatkowa jednostek samorządu terytorialnego sprowadza się do:

„(...)

- ustalania priorytetów w kierunkach wydatkowania środków,

- kształtowania ekonomicznej struktury wydatków,

- gospodarowania przyjętym majątkiem,

- kształtowania salda budżetu,

- zaciągania pożyczek komunalnych"18.

Te właściwości samodzielności wydatkowej jednostek samorządu terytorialnego są $\mathrm{w}$ praktyce ograniczone. Wynika to $\mathrm{z}$ tego, że dochody własne w znacznej części są uzupełniane z dochodów państwa na określonych zasadach i w części powiązanych z nakazami i limitami ich wydatkowania. W sumie zarówno o samodzielności dochodowej jak i wydatkowej decyduje poziom dochodów własnych, zakres wydatków sztywnych, zakres obligatoryjnych zadan ${ }^{19}$. Należy zgodzić się ze stwierdzeniem, że „Organy samorządowe nie mają na ogół pełnej samodzielności finansowej ani w sferze dochodowej, ani w sferze wydatkowej. Nie są bowiem jednostkami autonomicznymi, nie są również organami samofinansującymi się"20. Taka konstrukcja ma charakter ustrojowy i wynika z systemu decentralizacji finansów publicznych. Należy jednak zwrócić uwagę, że w odniesieniu do dochodów, które stanowią punkt wyjścia dla rozważań poświęconych samodzielności jednostek samorządu terytorialnego, najważniejszą rolę mają dochody własne. Problem jednak sprowadza się do tego, że zgodnie z obowiązującym prawem do tej kategorii zalicza się

16 K. Surówka, Samodzielność finansowa samorzq̨du terytorialnego w Polsce, Warszawa 2013, s. 23.

17 Ibidem, s. 25.

18 Ibidem, s. 26.

19 Ibidem, s. 26.

20 M. Kosek-Wojnar, K. Surówka, Podstawy finansów samorzadu terytorialnego, Warszawa 2007, s. 83. 
udziały w podatku dochodowym od osób fizycznych i w podatku dochodowym od osób prawnych, na poziom których samorząd terytorialny nie ma wpływu. Stąd interesująca jest propozycja wprowadzenia kategorii „własnego potencjału dochodowego", do którego zalicza się wpływy z udziałów w wymienionych wyżej podatkach, wpływy z podatku od nieruchomości, od środków transportowych i czynności cywilnoprawnych $^{21}$. Posługiwanie się tą kategorią pozwala nie tylko ustalić kondycję finansową jednostki samorządu terytorialnego, ale także ocenić jej możliwości rozwojowe. Aby tak było, konieczne jest, aby potencjał dochodowy jednostek samorządu terytorialnego zawierał środki niepodlegające zwrotowi, a pochodzące z budżetu Unii Europejskiej22.

Jak wskazano wyżej, ważnym elementem decydującym o zakresie samodzielności jednostek samorządu terytorialnego są wydatki. „Zasadniczo wydatki są finansowym odbiciem rozwiązań przyjętych w ustawach szczegółowych (...). Wydatków publicznych $\mathrm{z}$ reguły nie można oddzielić od zadań publicznych, formułowanych w przepisach prawnych. Są one bezpośrednią lub pośrednią konsekwencją regulacji dotyczących zadań i związanych z ich realizacją kompetencji”23. Ta specyfika powoduje, że katalog wydatków w ujęciu rodzajowym przyjmuje, w zasadzie, postać działową. Omawiając jednak wydatki w kontekście samodzielności trzeba jeszcze raz podkreślić, że istotne znaczenie w ich kształtowaniu ma podział na wydatki sztywne i pozostałe. Wynika to $z$ tego, że wpływ na te pierwsze ma obowiązek ich ponoszenia narzucony rygorystycznie, bowiem wydatki te w znacznej części związane są z obsługą długu. Zatem w tym przypadku samodzielność finansowa jest ograniczona w najwyższym stopniu. Niezależnie od tych obostrzeń dotyczących zarówno dochodów, jak i wydatków, jednostki samorządu terytorialnego muszą podejmować zarówno bieżące, jak i strategiczne decyzje, które odnoszą się w znacznej mierze do decyzji finansowych. W tym zakresie w literaturze wskazuje się, że niezbędne jest zachowanie następującej sekwencji: ,(..)

- formułowanie celu,

- określenie wyboru będącego pochodną dokonania wyboru,

- skonkretyzowanie wariantów decyzyjnych,

- ocenę hipotetycznych skutków realizacji poszczególnych wariantów (...)

- wybór wariantu (...)"24.

21 Por. T. Lubińska, S. Franek, M. Będzieszak, Potencjał dochodowy samorządu w Polsce. Na tle zmian ustawy o dochodach jednostek samorządu terytorialnego, Warszawa 2007, s. 77.

22 Por. Podstawy finansów i prawa finansowego, red. A. Drwiłło, Warszawa 2011, s. 576.

23 A. Borodo, op. cit., s. 243.

24 B. Filipiak, Finanse samorzqdowe. Nowe wyzwania bieżące i perspektywiczne, Warszawa 2011, s. 105. 


\section{Charakterystyka struktury systemu jednostek samorządu terytorialnego}

Aby ocenić jak funkcjonuje system jednostek samorządu terytorialnego, trzeba zanalizować dane skoncentrowane na dochodach i wydatkach w układzie względnym i w przeliczeniu na jednego mieszkańca oraz skonfrontować je z wynikami, będącymi miarą efektów finansowych. Pozwoli to na charakterystykę architektury systemu finansowego jednostek samorządu terytorialnego i wyprowadzenie wniosków dotyczących jego spójności.

W pierwszej kolejności zanalizowane zostaną wydatki (tab. 1).

\begin{tabular}{|c|c|c|c|c|c|}
\hline \multirow{2}{*}{$\begin{array}{c}\text { Rodzaj } \\
\text { wydatków }\end{array}$} & \multicolumn{5}{|c|}{ LATA } \\
\hline & 2010 & 2011 & 2012 & 2013 & 2014 \\
\hline 1. Oświata i wychowanie & 28,4 & 29,2 & 30,8 & 30,6 & 29,3 \\
\hline 2. Transport i łączność & 18,0 & 18,0 & 16,3 & 16,4 & 17,7 \\
\hline 3. Pomoc społeczna & 12,5 & 12,1 & 12,6 & 12,8 & 12,4 \\
\hline 4. Administracja publiczna & 8,4 & 8,5 & 8,8 & 9,1 & 8,7 \\
\hline 5. Gospodarka komunalna i ochrona środowiska & 5,7 & 5,2 & 5,0 & 5,6 & 6,4 \\
\hline 6. Kultura i ochrona dziedzictwa naturalnego & 3,9 & 3,7 & 3,8 & 3,7 & 3,9 \\
\hline 7. Gospodarka mieszkaniowa & 3,4 & 3,5 & 3,7 & 3,4 & 3,4 \\
\hline 8. Rolnictwo i łowiectwo & 2,8 & 3,0 & 2,6 & 2,4 & 2,5 \\
\hline 9. Kultura fizyczna i sport & 3,6 & 2,9 & 2,6 & 2,2 & 2,3 \\
\hline 10. Edukacyjna opieka wychowawcza & 2,3 & 2,4 & 2,5 & 2,6 & 2,5 \\
\hline 11. Ochrona zdrowia & 2,2 & 2,3 & 1,9 & 2,1 & \multirow{6}{*}{10,9} \\
\hline 12. Bezpieczeństwo i ochrona przeciwpożarowa & 2,2 & 2,0 & 2,0 & 2,0 & \\
\hline 13. Pozostałe zadania w zakresie polityki społecznej & 1,6 & 1,7 & 1,7 & 1,8 & \\
\hline 14. Różne rozliczenia & 1,7 & 1,6 & 1,6 & 1,4 & \\
\hline 15. Obsługa długu & 1,1 & 1,6 & 2,0 & 1,6 & \\
\hline 16. Pozostała & 2,2 & 2,3 & 2,1 & 2,3 & \\
\hline
\end{tabular}

Tabela 1. Struktura wydatków budżetowych jednostek samorządu terytorialnego

Źródło: Sprawozdanie z działalności regionalnych izb obrachunkowych i wykonania budżetu przez jednostki samorzq̨du terytorialnego wydatków w 2011, 2012, 2013, 2014, 2015, KRRIO, www.rio.gov.pl (dostęp 30.06.2015 r.). Obliczenia własne.

Struktura wydatków jednostek samorządu terytorialnego wyraźnie wskazuje trzy dominujące obszary działań. Jest to oświata i wychowanie, transport i łączność oraz pomoc społeczna. W tym układzie najbardziej stabilny poziom mają wydatki na pomoc społeczną. W okresie 20102014 stanowią niezmiennie niewiele ponad 12\%.

Jeszcze wyraźniej występują wskazane preferencje jeżeli zanalizuje się wydatki jednostek samorządu terytorialnego w przeliczeniu na 1 mieszkańca 
(tabela 2). Zróżnicowanie między trzema wymienionymi obszarami jest bardzo znaczne. Wydatki na oświatę i wychowanie w przeliczeniu na 1 mieszkańca rosną w okresie od 2010 roku do 2014 r. z 1322 zł do 1498 zł.

\begin{tabular}{|c|c|c|c|c|c|}
\hline \multirow{2}{*}{$\begin{array}{c}\text { Rodzaj } \\
\text { wydatków }\end{array}$} & \multicolumn{5}{|c|}{ LATA } \\
\hline & 2010 & 2011 & 2012 & 2013 & 2014 \\
\hline 1. Oświata i wychowanie & 1322 & 1388 & 1442 & 1461 & 1798 \\
\hline 2. Transport i łączność & 838 & 856 & 763 & 783 & 905 \\
\hline 3. Pomoc społeczna & 582 & 575 & 590 & 611 & 634 \\
\hline 4. Administracja publiczna & 391 & 404 & 412 & 435 & 445 \\
\hline 5. Gospodarka komunalna i ochrona środowiska & 265 & 247 & 234 & 267 & 327 \\
\hline 6. Kultura i ochrona dziedzictwa naturalnego & 181 & 176 & 118 & 177 & 199 \\
\hline 7. Gospodarka mieszkaniowa & 158 & 166 & 173 & 162 & 174 \\
\hline 8. Rolnictwo i łowiectwo & 130 & 143 & 122 & 115 & 128 \\
\hline 9. Kultura fizyczna i sport & 168 & 138 & 122 & 105 & 118 \\
\hline 10. Edukacyjna opieka wychowawcza & 107 & 114 & 117 & 124 & 128 \\
\hline 11. Ochrona zdrowia & 102 & 109 & 80 & 100 & \multirow{6}{*}{557} \\
\hline 12. Bezpieczeństwo i ochrona przeciwpożarowa & 102 & 95 & 94 & 96 & \\
\hline 13. Pozostałe zadania w zakresie polityki społecznej & 74 & 81 & 80 & 86 & \\
\hline 14. Różne rozliczenia & 79 & 76 & 75 & 67 & \\
\hline 15. Obsługa długu & 51 & 76 & 94 & 76 & \\
\hline 16. Pozostała & 102 & 109 & 98 & 110 & \\
\hline RAZEM & 4655 & 4754 & 4683 & 4775 & 5113 \\
\hline
\end{tabular}

Tabela 2. Wydatki budżetowe jednostek samorządu terytorialnego na 1 mieszkańca w zł

Źródło: Sprawozdanie z działalności regionalnych izb obrachunkowych i wykonania budżetu przez jednostki samorządu terytorialnego wydatków w 2011, 2012, 2013, 2014, 2015, KRRIO, www.rio.gov.pl (dostęp 30.06.2015 r.). Obliczenia własne.

Natomiast wydatki na 1 mieszkańca przeznaczone na transport i łączność są zmienne w czasie i wynosiły w 2010 roku 838 zł, spadły w 2012 roku do 763 zł i wzrosły w 2014 r. do 905 zł. Podobnie wydatki na oświatę i wychowanie na 1 mieszkańca rosły w okresie 2010-2014 od 582 zł do $634 \mathrm{zł}$.

W sumie zatem, te trzy obszary wydatków dominują w wydatkach ogółem, ale znaczną przewagę mają wydatki na oświatę i wychowanie.

Analiza wydatków nie wystarcza, aby omówić architekturę systemu finansowego jednostek samorządu terytorialnego. Trzeba rozważania rozszerzyć na źródła finansowania koncentrując się na dochodach. Chcąc orzec, w jakim stopniu jednostki samorządu terytorialnego maja samodzielność finansową, trzeba skonfrontować je z dochodami pozostałymi, którymi są dotacje celowe i subwencje ogólne. Problem jednak w tym, 
jak już wskazano, że zgodnie $\mathrm{z}$ obowiązującym prawem do dochodów własnych zalicza się udziały w podatku dochodowym od osób fizycznych $\mathrm{w}$ oraz $\mathrm{w}$ podatku dochodowym od osób prawnych. I nie budziłoby to wątpliwości, gdyż obywatele społeczności lokalnych i firmy, które są zlokalizowane na obszarach jednostek samorządu terytorialnego partycypują w dochodach budżetu państwa, gdyby nie fakt, że o tym, jak część podatków dochodowych przypada jednostkom samorządu terytorialnego decyduje władza centralna. Biorąc pod uwagę te zastrzeżenia, trzeba zanalizować strukturę dochodów jednostek samorządu terytorialnego.

Z danych wynika (tabela 3), że dochody własne wraz z udziałami w podatkach dochodowych stanowią $50 \%$ dochodów ogółem i, że udział ten w niewielkim stopniu ale wzrasta od 2010 roku, kiedy wynosił $48,8 \%$, do 50,7\% w 2014 roku. Znaczną część w tej strukturze stanowią udziały w podatku dochodowym, które wzrastają w niewielkim stopniu od 20,3\% w 2010 roku do 21,4\% w 2014 mroku. Natomiast dochody, które odpowiadają w pełnym tego słowa znaczeniu dochodom własnym, czyli dochody z podatków lokalnych i opłat maja tendencję wzrostową, przy czym wyraźny skok nastąpił w 2014 roku. Zmiana ta nastąpiła z 12,5\% w 2010 roku do 18\% w 2014 roku. Można to uznać za zjawisko korzystne z punktu widzenia zakresu samodzielności finansowej jednostek samorządu terytorialnego. Do tego jednak trzeba dodać dochody z majątku, które w niewielkim stopniu, ale obniżają się z 3,9\% w 2010 roku do 3,1\% w 2014.

\begin{tabular}{|l|r|r|r|r|r|}
\hline \multirow{2}{*}{\multicolumn{1}{|c|}{ Źródło dochodów }} & \multicolumn{5}{|c|}{ LATA } \\
\cline { 2 - 6 } & 2010 & 2011 & 2012 & 2013 & 2014 \\
\hline 1. Dochody własne w tym: & 48,4 & 48,9 & 49,1 & 50,0 & 50,7 \\
\hline $\begin{array}{l}\text { udziały w podatku dochodowym } \\
\text { wpływy z podatku i opłat } \\
\text { dochody z majątku }\end{array}$ & 20,3 & 21,2 & 21,2 & 21,1 & 21,4 \\
\cline { 2 - 6 } & 12,5 & 12,6 & 13,0 & 13,3 & 18,0 \\
\cline { 2 - 6 } & 3,9 & 3,8 & 3,8 & 3,8 & 3,1 \\
\hline 2. Dotacje celowe & 22,8 & 22,9 & 22,4 & 22,0 & 22,9 \\
\hline 3. Subwencje ogólne & 28,8 & 28,2 & 28,6 & 27,9 & 26,3 \\
\hline
\end{tabular}

Tabela 3. Struktura dochodów jednostek samorzadu terytorialnego Źródło: Sprawozdanie z działalności regionalnych izb obrachunkowych i wykonania budżetu przez jednostki samorzq̨du terytorialnego wydatków w 2011, 2012, 2013, 2014, 2015, KRRIO, www.rio.gov.pl (dostęp 30.06.2015 r.).

Pozostałe dochody to, jak wskazano wyżej, dotacje celowe i subwencje ogólne. Te pierwsze utrzymują się na podobnym poziomie, od 22,8\% w 2010 r. do 22,9\% w 2014 roku. Należy jednak brać pod uwagę, że dysponowanie nimi przez jednostki samorządu terytorialnego jest ograniczone do wykonawstwa, a nie możliwości dokonania zmiany ich przeznaczenia. Z założenia inną rolę odgrywa subwencja ogólna, która wykazuje 
tendencję malejącą od 28,8\% w 2010 roku do 26,3\% w 2014 roku. Nie należy jednak zapominać, że znaczna cześć subwencji jest przeznaczona na oświatę, a fakt, że jest to obszar, w którym wydatki jednostek samorządu terytorialnego są najwyższe powoduje refleksje nad tendencją do ich zmniejszenia. Przedstawioną analizę warto uzupełnić o dane dotyczące dochodów jednostek samorządu terytorialnego na 1 mieszkańca.

\begin{tabular}{|l|r|r|r|r|r|}
\hline \multirow{2}{*}{\multicolumn{1}{|c|}{ Źródło dochodów }} & \multicolumn{5}{|c|}{ LATA } \\
\cline { 2 - 6 } & 2010 & 2011 & 2012 & 2013 & 2014 \\
\hline 1. Dochody własne w tym: & 2063 & 2193 & 2261 & 2383 & 2560 \\
\hline $\begin{array}{l}\text { udziały w podatku dochodowym } \\
\text { wpływy z podatku i opłat } \\
\text { dochody z majątku }\end{array}$ & 865 & 951 & 976 & 1005 & 1081 \\
\cline { 2 - 6 } & 533 & 565 & 599 & 634 & 909 \\
\cline { 2 - 6 } & 166 & 170 & 175 & 181 & 157 \\
\hline 2. Dotacje celowe & 972 & 1027 & 1031 & 1048 & 1156 \\
\hline 3. Subwencje ogólne & 1228 & 1264 & 1317 & 1329 & 1328 \\
\hline Dochody ogółem & 4263 & 4485 & 4604 & 4765 & 5050 \\
\hline
\end{tabular}

Tabela 4. Dochody budżetowe jednostek samorządu terytorialnego na 1 mieszkańca ( $w$ zt) Źródło: Sprawozdanie z działalności regionalnych izb obrachunkowych i wykonania budżetu przez jednostki samorzqdu terytorialnego wydatków w 2011, 2012, 2013, 2014, 2015, KRRIO, www.rio.gov.pl (dostęp 30.06.2015 r.).

Dochody własne na jednego mieszkańca wyraźnie rosną z 2063 zł w 2010 roku do 2560 zł w 2014 roku. Charakterystyczne jest przy tym, że w większym stopniu rosną wpływy z podatków lokalnych i opłat, z 533 zł w 2010 roku do 909 zł w 2014, niż udział w podatku dochodowym, który też wzrasta, ale w mniejszym stopniu, z 865 zł w 2010 roku do 1081 zł w 2014 r.

Dochody inne niż własne, na 1 mieszkańca, także rosną, ale w mniejszym stopniu niż dochody własne. Wysokość dotacji celowych rośnie z 972 zł w 2010 roku do 1156 zł w 2014, a subwencji ogólnych z 1228 zł w 2010 roku do $1328 \mathrm{zł} \mathrm{w} 2014$ roku.

Ponadto charakterystyczne jest to, że dochody ogółem na 1 mieszkańca rosną zdecydowanie z 4263 zł w roku 2010 do 5050 zł w 2014 r.

Ważnym uzupełnieniem analizy gospodarki finansowej jednostek samorządu terytorialnego jest ich aktywność w programach europejskich. Wymaga to jednak partycypacji w ich finansowaniu, co przekłada się na wydatki przeznaczone na ten cel. Udział ten w wydatkach ogółem jednostek samorządu terytorialnego jest zmienny (tabela 5). Najwyższy miał miejsce w 2011 roku i wynosił 13,6\%, a w 2014 roku powrócił do poziomu z 2010 roku i wynosił 12,2\%. Zmienność w tym zakresie jest uzasadniona, bowiem $z$ reguły środki unijne przeznaczone są na inwestycje, które mogą być realizowane w cyklu dłuższym niż jeden rok. 
Udział wydatków na programy i projekty realizowane ze środków zagranicznych do wydatków ogółem

\begin{tabular}{|c|c|c|c|c|}
\hline \multicolumn{5}{|c|}{ LATA } \\
\hline 2010 & 2011 & 2012 & 2013 & 2014 \\
\hline 12,3 & 13,6 & 11,9 & 11,3 & 12,2 \\
\hline
\end{tabular}

Tabela 5. Udział wydatków jednostek samorządu terytorialnego na programy i projekty realizowane ze środków zagranicznych w wydatkach ogółem w \% Źródło: Sprawozdanie z działalności regionalnych izb obrachunkowych i wykonania budżetu przez jednostki samorzqdu terytorialnego wydatków w 2011, 2012, 2013, 2014, 2015, KRRIO, www.rio.gov.pl (dostęp 30.06.2015 r.).

Na zakończenie prezentowanej analizy trzeba zwrócić uwagę na to, jak przedstawiają się wyniki finansowe jednostek samorządu terytorialnego.

Charakterystyczne jest, że liczba jednostek mających nadwyżkę wzrasta, a liczba jednostek mających deficyt maleje (tabela 6), przy czym nadwyżka w stosunku do dochodów ma mniejszy udział niż deficyt.

\begin{tabular}{|l|r|r|r|r|r|}
\hline \multirow{2}{*}{\multicolumn{1}{|c|}{ Liczba jednostek }} & \multicolumn{5}{|c|}{ LATA } \\
\cline { 2 - 6 } & 2010 & 2011 & 2012 & 2013 & 2014 \\
\cline { 2 - 6 } & 319 & 857 & 1542 & 1674 & 1358 \\
\hline Nadwyżka w relacji do dochodów & 3,8 & 3,8 & 4,2 & 3,7 & Brak \\
\hline Liczba jednostek & 2490 & 1452 & 67 & 1135 & 1451 \\
\hline Deficyt w relacji do dochodów & 10,9 & 8,9 & 5,4 & 5,1 & 6,4 \\
\hline
\end{tabular}

Tabela 6. Wyniki budżetów jednostek samorządu terytorialnego Źródto: Sprawozdanie z działalności regionalnych izb obrachunkowych i wykonania budżetu przez jednostki samorzq̨du terytorialnego wydatków w 2011, 2012, 2013, 2014, 2015, KRRIO, www.rio.gov.pl (dostęp 30.06.2015 r.).

Przeprowadzona analiza prowadzi do następujących wniosków:

- Wydatki j.s.t. koncentrują się na trzech kierunkach: oświata i wychowanie, transport i łączność oraz pomoc socjalna. Ich poziom jest jednak bardzo zróżnicowany, na co wyraźnie wskazuje ich wysokość przeliczona na 1 mieszkańca.

- Dochody jednostek samorządu terytorialnego formalnie zaliczane do kategorii dochodów własnych, stanowią około 50\%. Świadczy to o uzależnieniu od tych środków, na wysokość których samorząd nie ma wpływu. Korzystny jest wzrost dochodów z podatków i opłat lokalnych.

- Pozytywnym objawem jest wzrost dochodów własnych na 1 mieszkańca.

- Zjawiskiem, świadczącym o aktywności jednostek samorządu terytorialnego jest zaangażowanie środków w realizację programów europejskich.

- Zaprzeczeniem obiegowych opinii jest wzrost liczby jednostek samorządu terytorialnego mających nadwyżkę budżetową i malejąca liczba posiadających deficyt. 


\section{Harmonia czy chaos architektury systemu finansowego jednostek samorządu terytorialnego?}

Przeprowadzone powyżej rozważania umożliwiają konkluzje zmierzające w kilku kierunkach. Po pierwsze, czy gospodarka środkami publicznymi na poziomie jednostek samorządu terytorialnego ma postać systemu finansowego? Po drugie, jak przebiega konfrontacja miedzy założeniami zawartymi w teorii samorządów terytorialnych a praktyką? Po trzecie, czy przyjęte rozważania w zakresie finansów pozwalają uznać, że jednostki samorządu terytorialnego charakteryzują się samodzielnością finansową?

Odpowiedź na powyższe pytania prowadzi do sformułowania wniosków, które otwierają drogę do dyskusji.

Wnioski te są następujące:

- Architektura finansów jednostek samorządu terytorialnego jest skonfigurowana niekonsekwentnie.

- Brak konsekwencji w budowie systemu finansowego jednostek samorządu terytorialnego wywołuje wątpliwości, czy można uznać, że jest to system, który cechuje się wewnętrzną spójnością.

- Następstwem związanym z ułomnością systemu finansowego jednostek samorządu terytorialnego jest trudność z pełnej realizacji ich celów i funkcji.

- Przejawem wybiórczego działania jednostek samorządu terytorialnego jest struktura wydatków skoncentrowana na trzech obszarach: edukacji, komunikacji i potrzebach socjalnych.

- Charakterystyczną cechą gospodarki finansowej po stronie dochodów jest około 50\% udział środków własnych - łącznie z udziałami w podatkach dochodowych. To jest podstawą do ograniczonej samodzielności finansowej.

- Należy liczyć się ze zmianą możliwości finansowania potrzeb społeczności lokalnych wraz z zahamowaniem dopływu środków europejskich.

- Wskazane okoliczności prowadzą do stwierdzenia, że architektura systemu finansów jednostek samorządu terytorialnego jest ułomna i wymaga korekt, głownie zmierzających do zwiększenia samodzielności finansowej, szerszego zakresu realizacji ich funkcji, rozszerzenia dochodów własnych np. przez zmianę systemu partycypacji j.s.t. w podatkach dochodowych. 


\section{Bibliografia}

Bolland S., Wstęp do nauki finansów, Warszawa 1979.

Borodo A., Samorząd terytorialny. System prawnofinansowy, Warszawa 2004.

Dupret B., Prawo w naukach społecznych, Oficyna Naukowa, Warszawa 2010.

Encyklopedia logiki, Wrocław-Warszawa-Kraków 1970.

Encyklopedia Organizacji i Zarządzania, Warszawa 1981.

Filipiak B., Finanse samorządowe. Nowe wyzwania bieżace i perspektywiczne, Warszawa 2011.

Kogut-Jaworska M., Instrumenty interwencjonizmu lokalnego w stymulowaniu rozwoju gospodarczego, Warszawa 2008.

Kosek-Wojnar M., Surówka K., Podstawy finansów samorządu terytorialnego, Warszawa 2007.

Lubińska T., Franek S., Będzieszak M., Potencjat dochodowy samorzadu w Polsce na tle zmian ustawy o dochodach jednostek samorzadu terytorialnego, Warszawa 2007.

Moździerz A., Nierównowaga finansów publicznych, Warszawa 2009.

Owsiak S., Finanse publiczne. Teoria i praktyka, Warszawa 2005.

Podstawy finansów i prawa finansowego, red. A. Drwiłło, Warszawa 2011.

Pszczołowski T., Mała encyklopedia prakseologii i teorii organizacji, Wrocław-Warszawa, 1978.

Sprawozdanie z działalności regionalnych izb obrachunkowych i wykonania budżetu przez jednostki samorzadu terytorialnego wydatków w 2011, 2012, 2013, 2014, 2015, KRRIO, www. rio.gov.pl (dostęp 30.06.2015 r.).

Surówka K., Samodzielność finansowa samorzqdu terytorialnego w Polsce, Warszawa 2013. 